\title{
Analisis Perencanaan Pola Operasi Armada Kapal Penyeberangan: Studi Kasus Pelabuhan Ujung-Kamal
}

\author{
Achmad Muchlis Sodik, Achmad Mustakim, dan Pratiwi Wuryaningrum \\ Departemen Teknik Trasportasi Laut, Fakultas Teknologi Kelautan, \\ Institut Teknologi Sepuluh Nopember (ITS) \\ e-mail:muchlisssodik@seatrans.ac.id.,mustakim@seatrans.ac.id,pratiwi@its.ac.id
}

\begin{abstract}
Abstrak-Sebelum beroperasinya Jembatan pada tahun 2009, Pelabuhan Kamal adalah pelabuhan penyebrangan di Kecamatan Kamal, Kabupaten Bangkalan. Pelabuhan penyebrangan Kamal Madura merupakan pelabuhan angkutan penyeberangan antar pulau yang menghubungkan Pulau Madura dengan Pulau Jawa, dengan jarak tempuh sekitar 2,5 mil laut dan lama waktu pelayaran kurang lebih 30-45 menit. Sejak beroperasinya Jembatan Suramadu, pengguna pelabuhan ini mengalami penurunan. Sehingga menyebabkan PT ASDP Ujung-Kamal Mengurangi armada yang dari awalnya memiliki 19 armada dengan waktu operasional 24 jam menjadi 3 armada dengan waktu 15 jam saja. Tidak hanya itu, jumlah armada yang beroperasi terkadang tidak menentu sehingga mengakibatkan jadwal yang ada menjadi tidak konsisten. tidak sedikit penumpang yang harus menunggu atau tertinggal oleh kapal. Tugas akhir ini bertujuan untuk merencanakan pola operasi Penyeberangan Ujung-Kamal yang optimal, setelah melakukan optimasi dari 3 kapal yang beroperasi terpilih 2 kapal yaitu KMP Jokotole dan KMP Gajah Mada. jadwal penyeberangan di rubah hanya melayani 8 dan 10 trip dalam satu hari. Dari hasil optimasi penjadwalan tersebut di dapatkan minimum unit cost yaitu sebesar Rp. 14.887.966 per hariuntuk KMP Gajah Mada dan Rp. Rp11.230.715 per hari untuk KMP Jokotole.
\end{abstract}

Kata Kunci- Pelabuhan Kamal-Ujung, Kapal penyeberangan, penumpang, Jadwal Kapal

\section{PENDAHULUAN}

$S_{\mathrm{P}}^{\mathrm{E}}$ EBELUM beroperasinya Jembatan pada tahun 2009, Pelabuhan Kamal adalah pelabuhan penyebrangan di Kecamatan Kamal, Kabupaten Bangkalan, terletak pada posisi $112^{\circ} 45^{\prime} 5$ Bujur Timur dan $07^{\circ} 11^{\prime} 40$ Lintang Selatan. Pelabuhan penyebrangan Kamal Madura merupakan pelabuhan angkutan penyeberangan antar pulau yang menghubungkan Pulau Madura dengan Pulau Jawa. Pelabuhan ini menghubungkan antara Pulau Madura dengan Pelabuhan Ujung yang terletak di Kota Surabaya[1], dengan jarak tempuh sekitar 2,5 mil laut dan lama waktu pelayaran kurang lebih 25-30 menit[2]. Pelabuhan Kamal Madura merupakan pintu gerbang utama Pulau Madura sejak zaman Belanda. Sejak zaman tersebut Pelabuhan Kamal Madura memiliki peranan yang sangat penting dalam hal transportasi dan juga perekonomian[3]. Seiring dengan berjalannya waktu, dari tahun ke tahun terjadi perkembangan yang sangat signifikan pada Pelabuhan Kamal ini. Saat beberapa tahun lalu Pelabuhan Kamal Madura ini sangat ramai, hiruk pikuk di pelabuhan ini hampir tidak pernah beristirahat, setiap harinya banyak orang hilir mudik memasuki Pelabuhan Kamal, Pelabuhan ini mempunyai fasilitas yaitu 3 dermaga, garbata dan beberapa kapal yang terkenal kecil. Kapal yang beroperasi disini pun namanya cukup unik. Contohnya KMP Jokotole, KMP Trunojoyo, KMP Potre Koneng, bahkan KMP selat madura 1 dan 2. Kebanyakan nama dari kapal tersebut berasal dari nama tokoh terkemuka di pulau madura. Penyeberangan dari Pelabuhan Kamal ke Pelabuhan Ujung Surabaya ditempuh sekitar 30 menit menggunakan kapal ferry melintasi Selat Madura. Sejak beroperasinya Jembatan Suramadu yang di harapkan dapat menumbuhkan perekonomian di Madura[4],akan tertapi pengguna pelabuhan ini mengalami penurunan drastis (mencapai hingga 40\%)[5]. Karena kecenderungan kendaraan untuk melewati Jembatan Suramadu dibandingkan dengan pelabuhan Kamal[6] Sehingga menyebabkan PT ASDP Ujung-Kamal Mengurangi armada yang dari awalnya memiliki 19 armada dengan waktu operasional 24 jam menjadi 3 armada dengan waktu 16 jam saja. Tidak hanya itu, jumlah armada yang beroperasi terkadang tidak menentu sehingga mengakibatkan jadwal yang ada menjadi tidak konsisten. tidak sedikit penumpang yang harus menunggu atau tertinggal oleh kapal.

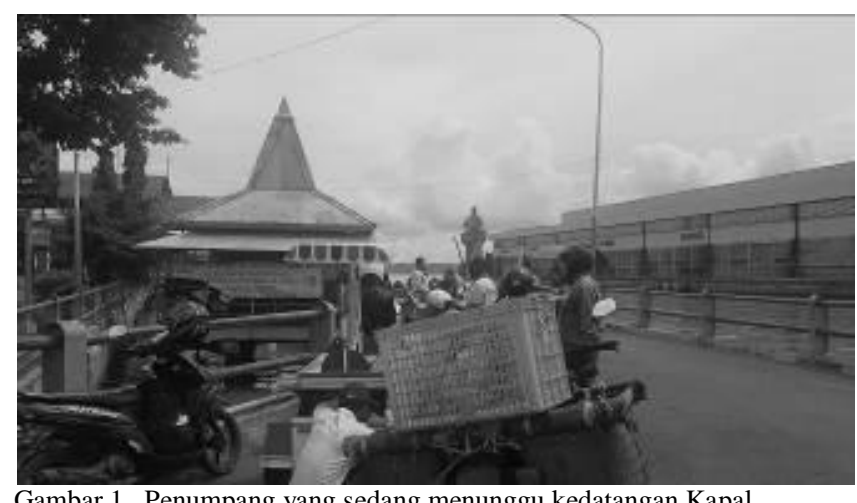

Gambar 1. Penumpang yang sedang menunggu kedatangan Kapal.

Gambar 1 menunjukkan ketidak pastian jadwal penyeberangan mengakibatkan para penumpang tidak memiliki acuan keberangkatan dan kedatangan kapal sehingga tidak sedikit penumpang yang menunggu kedatangan kapal dengan sangat lama.

\section{METODE PENELITIAN}

Dalam penelitian ini mengidentifikasi masalah dengan melakukan wawancara terhadap penumpang penyeberangan Ujung-Kamal dan mencari data kapal ke perusahaan pelayaran yang melayani rute tersebut dengan metode pengumpulan data dalam penelitian adalah metode pengumpulan secara langsung (primer) dan tidak langsung (sekunder). Tahap selanjutnya adalah pengolahan data yang 
telah didapat lalu tahap berikutnya dengan mengoptimasi data yang telah diolah dan mensensitivitaskannya .

\section{GAMBARAN UMUM}

\section{A. Lokasi Pelabuhan Ujung-Kamal}

Lokasi yang dijadikan studi kasus dalam pengerjaan tugas akhir ini dilakukan di pelabuhan penyeberangan UjungKamal, Pelabuhan penyebrangan Kamal Madura merupakan pelabuhan angkutan penyeberangan antar pulau yang menghubungkan Pulau Madura dengan Pulau Jawa.

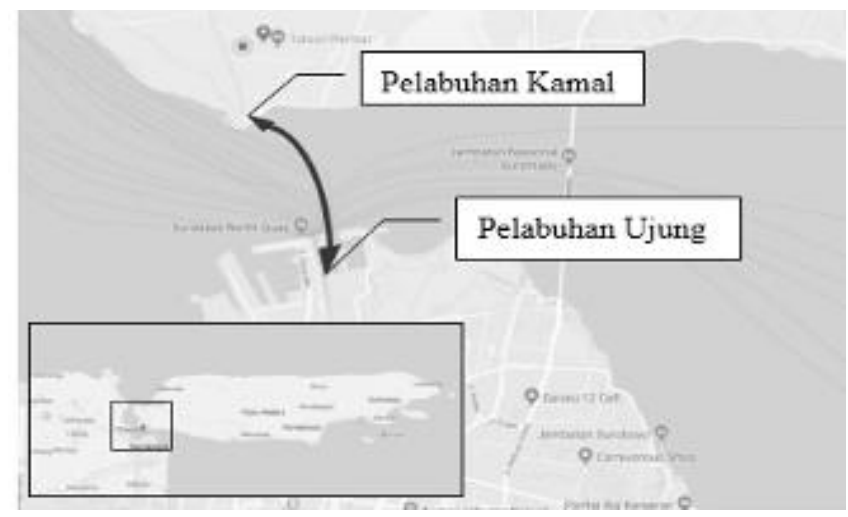

Gambar 2. Peta Rute Penyeberangan Ujung-Kamal.

Gambar 2 Jarak antara Pelabuhan penyebrangan Ujung dengan Pelabuhan penyebrangan Kamalberjarak tempuh sekitar 3 mil laut dan lama waktu pelayaran kurang lebih 45 menit. sebelum beroprasinya suramadu pada tahun 2009, Pelabuhan Ujung-kamal merupakan pelabuhan tersibuk seasia tenggara.

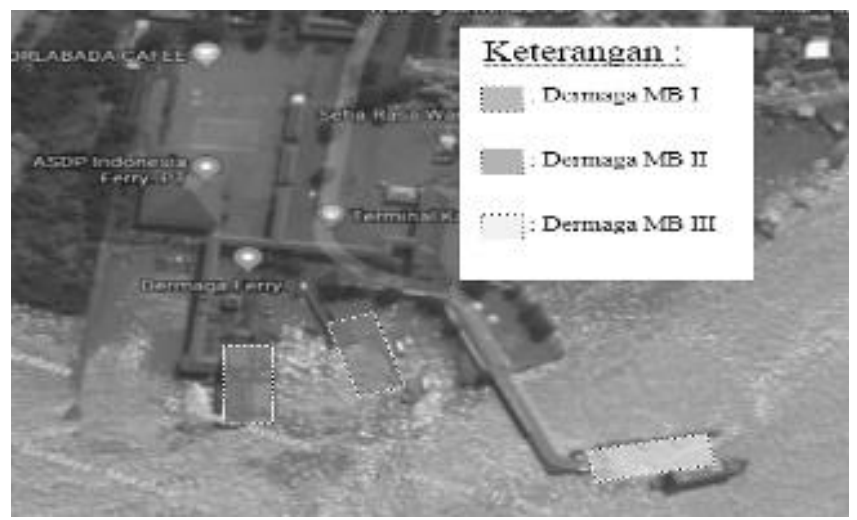

Gambar 3. Pelabuhan Kamal.

Gambar 3 Pelabuhan kamal memiliki 3 dermaga yang berjenis Mobile Bridgeatau biasa di sebut dermaga MB, setiap dermaga MB memiliki fasilitas yang berbeda-beda. Dermaga MB I terletak pada paling barat pelabuhan dengan memiki fasilitas berupa garbarata sehingga memudahkan penumpang untuk naik ke atas kapal tanpa harus terhalang dengan kendaraan bermotor, Dermaga MB II terletak di tengah-tengah antara dermaga MB I dan MB III, dermaga MB II ini tidak memiliki fasilitas seperti dermaga lainya. Dermaga ini hanya memiliki jalan yang di beri bagunan untuk memeriksa tiket dan pagar untuk penumpang yang tidak memakai kendaraan sehingga penumpang yang berjalan kaki terhindar dari kendaraan yang akan masuk atau keluar dari dalam kapal dan dermaga MB III terletak pada timur pelabuhan dimana dermaga ini tidak memiliki fasilitas seperti halnya dermaga MB I yakni garbarata akan tetapi dermaga MB III tetap memiliki jalur khusus penumpang yang hendak naik atau turun dari kapal sehingga tidak menggangu pengguna kendaraan bermotor atau sebaliknya. Jalur khusus tersebut di beri pagar pelindung agar penumpang yang berjalan kaki tidak di tabrak oleh kendaraan bermotor selain itu juga jalur khusus tersebut terdapat kanopi atau atap sehingga penumpang tidak terkena hujan di saat musim penghujan.

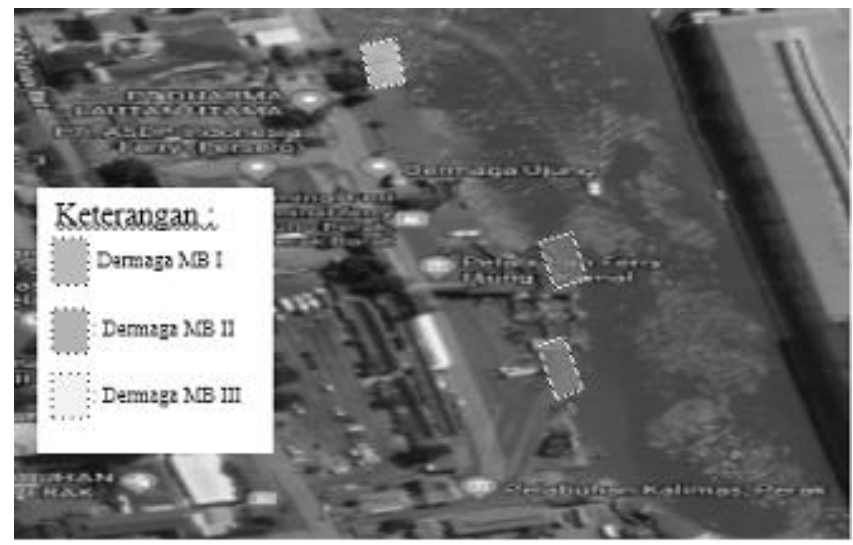

Gambar 4. Pelabuhan Ujung.

Gambar 4 Pelabuhan penyeberangan ujung memiliki 3 Dermaga Mobile Bridge atau biasa disebut Dermaga MB di setiap dermaga yang ada di pelabuhan ujung, memiliki fasilitas yang berbeda-beda, Dermaga MB I yang di miliki pelabuhan penyeberangan Ujung terletak pada selatan pelabuhan ini memiliki garbarata yang dimana dapat memudahkan penumpang yang berjalan kaki, Sama halnya dengan dermaga MB I, dermaga MB II yang terletak di tengah- tengah antara dermaga MB I dan dermaga MB III ini memiliki fasilitas garbarata dan Untuk dermaga MB III tidak di lengkapi oleh garbarata, sehingga penumpang yang berjalan kaki bercampur dengan penumpang yang menggunakan kendaraan bermotor . akan tetapi dermaga MB III ini sudah lama tidak di operasikan mengingat jumlah armada yang sedikit sehingga hanya dermaga MB I dan dermaga MB II saja yang di operasikan

\section{B. Data Penumpang}

Data yang telah dikumpulkan dengan metode secara tidak langsung (sekunder) dengan mengambil data ke perusahaan pelayaran yang melayani rute Ujung-Kamal. Dalam pengambilan data, data penumpang yang menggunakan jasa penyeberangan rute Ujung-kamal selama 1 (satu) Bulan pada tahun 2017.

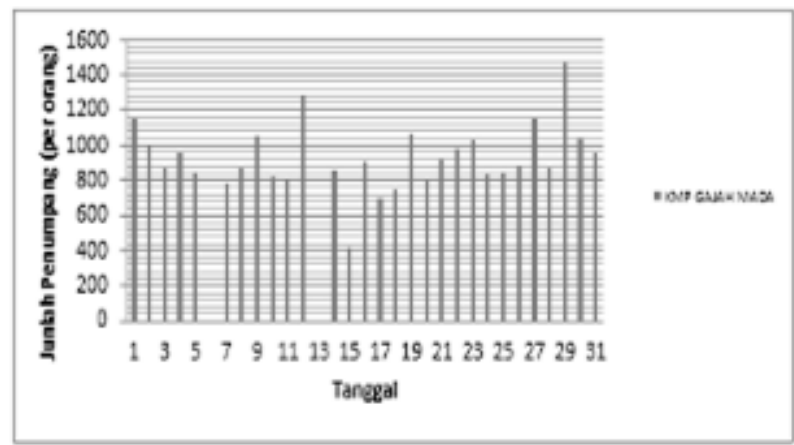

Gambar 5. Data Penumpang KMP Gajahmada Bulan Oktober 2017.

Gambar 5 Jumlah pengguna jasa penyeberangandiKMP Gajah Madamengalami naik turun, rata-rata Jumlah penumpang dalam bulan Oktober di tahun 2017 adalah 868 Orang, untuk jumlah tertinggi pada bulan tersebut mencapai 1471 orang dan jumlah terrendah jumlah penumpang KMP Gajah Mada mencapai 423 Orang. Total penumpang pada bulan tersebut di KMP Gajah mada berjumlah 26911 orang, 
total tersebut paling sedikit dari pada total penumpang kapal lainnya.

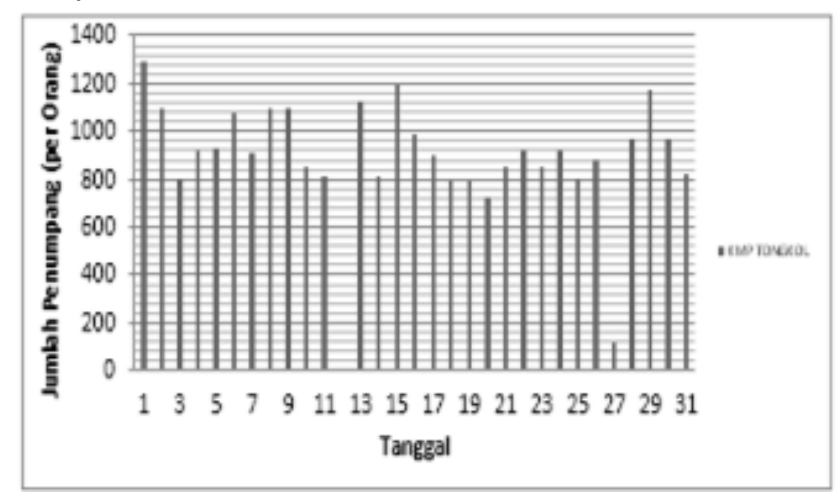

Gambar 6. Penumpang KMP Tongkol Bulan Oktober 2017.

Gambar 6 Jumlah pengguna jasa penyeberangan di KMP Tongkol mengalami naik turun, rata-rata Jumlah penumpang dalam bulan Oktober di tahun 2017 adalah 886 Orang, untuk jumlah tertinggi pada bulan tersebut mencapai 1296 orang dan jumlah terrendah jumlah penumpang KMP Tongkol mencapai 113 Orang. Total penumpang pada bulan tersebut di KMP Tongkol berjumlah 27474 orang, total tersebut lebih banyak dari total penumpang kapal KMP Gajah Mada.

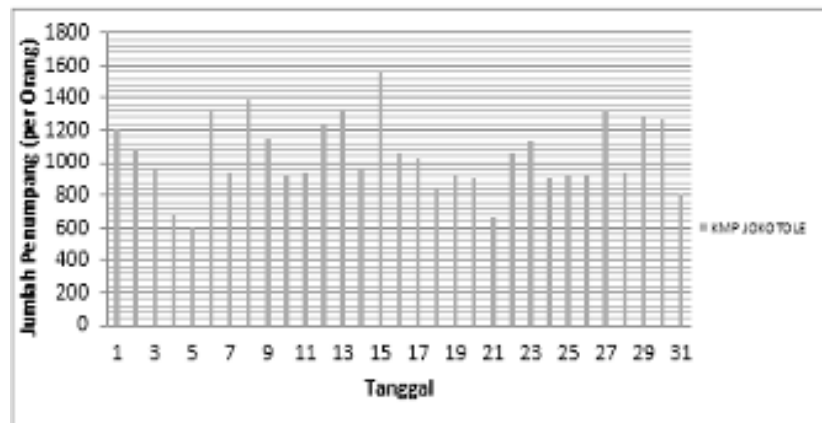

Gambar 7. Penumpang KMP Jokotole Bulan Oktober 2017.

Gambar 7 Jumlah pengguna jasa penyeberangan di KMP Jokotole mengalami naik turun, rata-rata Jumlah penumpang dalam bulan Oktober di tahun 2017 adalah 1040 Orang, jumlah tersebut adalah jumlah rata-rata penumpang terbanyak dari jumlah rata-rata penumpang kapal lainnya. untuk jumlah tertinggi pada bulan tersebut mencapai 1558 orang dan jumlah terrendah jumlah penumpang KMP Jokotole mencapai 604 Orang. Total penumpang pada bulan tersebut di KMP Jokotole berjumlah 32253 orang, total tersebut paling banyak dari total penumpang kapal lainnya.

\section{Data Kapal}

Kapal Ro-royang dijadikan penelitian dalam Tugas Akhir ini berjumlah 2 kapal milik PT. ASDP Persero dan 1 kapal milik PT DARMA LAUTAN UTAMA yang beroperasi di pelabuhan Ujung-kamal. ini adalah data dari kapal yang beroperasi di pelabuhan Ujung-Kamal.

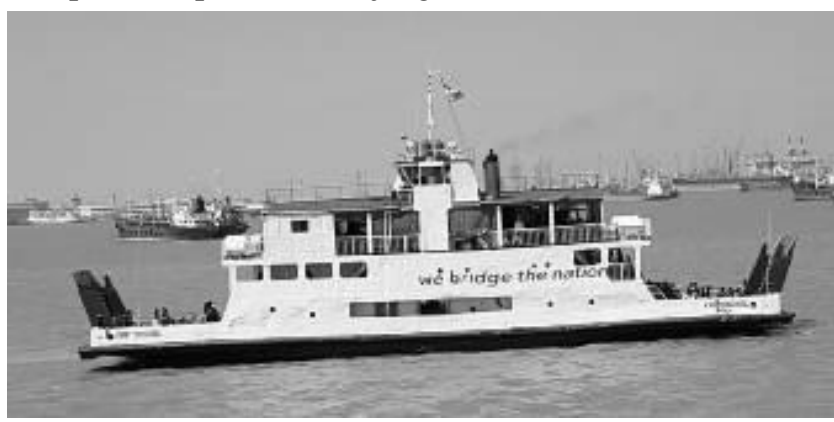

Gambar 8. Kapal KMP Tongkol.
Gambar 8. KMP Tongkol memiliki Panjang keseluruhan sepanjang: $40.90 \mathrm{~m}$, dengan panjang garis air: $36.74 \mathrm{~m}$, lebar dari KMP Tongkol : $10.20 \mathrm{~m}$, kedalaman sarat air KMP Tongkol sedalam : 2.5m, Tinggi dari KMP Tongkol : $3.8 \mathrm{~m}$ untuk Kecepatan Dinas : 4 Knot,Kapasitas Penumpang: 220 Orang, Tahun Pembuatan : 1970,DWT/GRT: 259 Ton Klasifikasi dari KMP Tongkol adalah : BKI

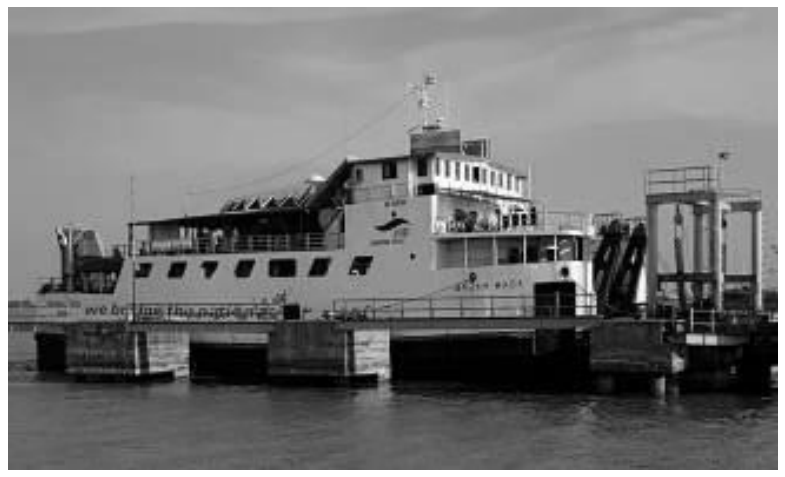

Gambar 9. Kapal KMP Gajah Mada.

Gambar 9. KMP Gajah Mada memiliki Panjang keseluruhan sepanjang: $41.86 \mathrm{~m}$, dengan panjang garis air: 38.50 m, lebar dari KMP Gajah Mada : 11.30 m, kedalaman sarat air KMP Gajah Mada sedalam : 3.4 m,Tinggi dari KMP Tongkol : 3.8 m untuk Kecepatan Dinas : 6 Knot,Kapasitas Penumpang: 290 Orang, Tahun Pembuatan : 1969, DWT/GRT: 512 Ton Klasifikasi dari KMP Gajah Mada adalah : BKI

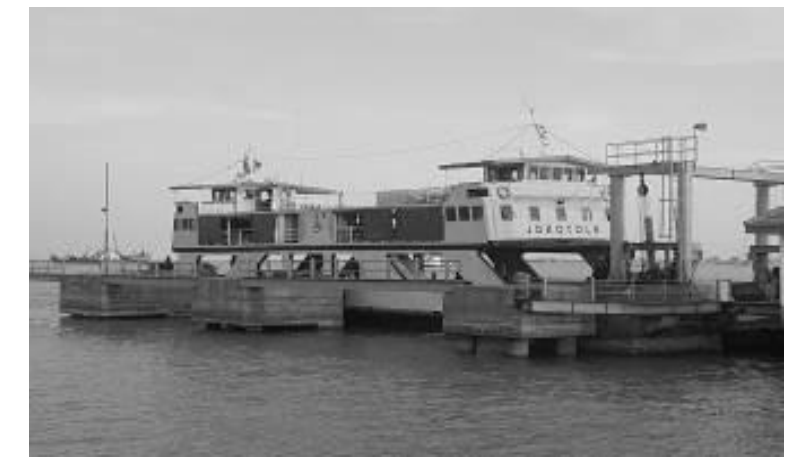

Gambar 10. Kapal KMP Jokotole.

Gambar 10. KMP Jokotole memiliki Panjang keseluruhan sepanjang: $31.50 \mathrm{~m}$, dengan panjang garis air: $29.94 \mathrm{~m}$, lebar dari KMP Jokotole: $9.00 \mathrm{~m}$, kedalaman sarat air KMP Jokotole sedalam: $1.3 \mathrm{~m}$, Tinggi dari KMP Jokotole : $3.1 \mathrm{~m}$ untuk Kecepatan Dinas: 8 Knot, Kapasitas Penumpang: 220 Orang, Tahun Pembuatan: 1976, DWT/GRT: 192 Ton Klasifikasi dari KMP Jokotole adalah: BKI

\section{Pola Operasi Penyeberangan Pelabuhan Ujung-Kamal}

Dengan jumlah armada yang berbeda, masing-masing perusahaan pelayaran membagi waktu jadwal keberangkatan armadanya, Kapal penyeberangan memiliki pola operasi keberangkatan yang diilustrasikan pada gambar 11.

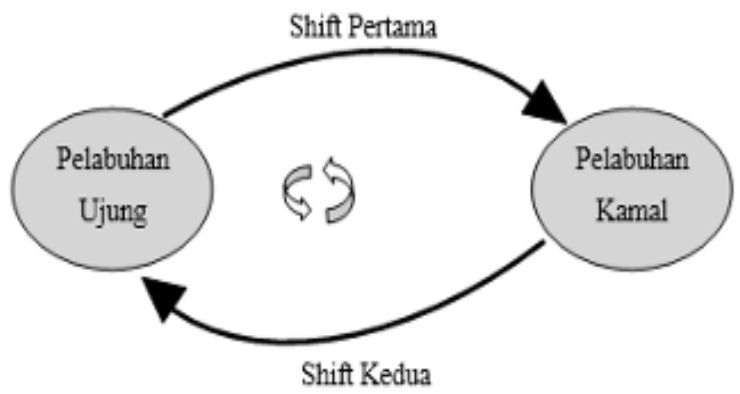

Gambar 11. Pola Operasi Penyeberangan Pelabuhan Ujung-Kamal. 
Gambar 11. Dimana pola operasi untuk penyeberangan pelabuhan Ujung-Kamal bertipe Port to Port, saat kapal yang berada di pelabuhan Ujung mendapatkan shift pertama dan kapal yang berada di pelabuhan kamal mendapatkan shift kedua. Pada waktu yang bersamaan kedua kapal berangkat dari pelabuhan awal dan akan tiba di pelabuhan tujuan dengan waktu yang bersamaan pula, pola tersebut akan berlangsung hingga jadwal tersebut selesai.

\section{ANALISIS DAN PEMBAHASAN}

\section{A. Survei Penumpang}

Untuk mendukung penelitian ini, penulis melakukan survei kelapangan dan menyebarkan kuesioner di pelabuhan penyeberangan Ujung-Kamal, jumlah dari responden dalam penelitian ini berjumlah 60 orang. Berdasarkan kuesioner yang disebarkan kepada responden, hasil penelitian ini dapat dijabarkansebagaiberikut

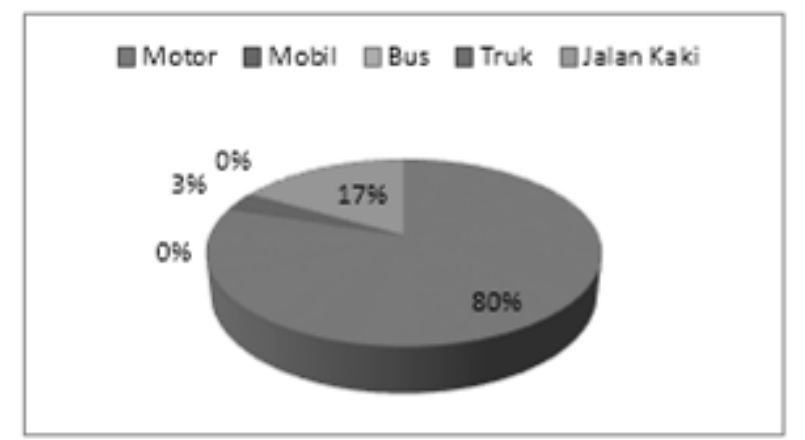

Gambar 12. Jenis Kendaraan.

Gambar 12. diatas menunjukan respon responden mengenai Jenis kendaraan yang yang digunakan saat menggunakan jasa penyeberangan Ujung-Kamal. $80 \%$ responden menggunakan Motor, lalu mobil dengan 3\%, untuk truk dan bus $0 \%$ dan jalan kaki sebesar 17\%. Dari hasil tersebut presentase terbanyakl adalah motor dengan presentase $80 \%$

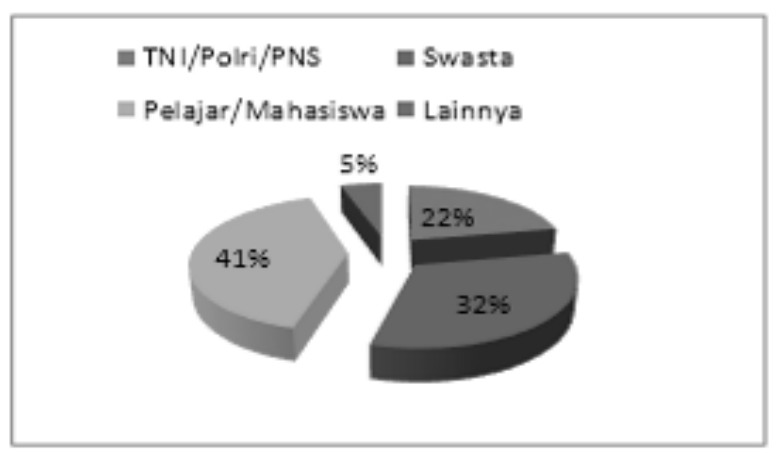

Gambar 13. Pekerjaan Responden.

Gambar 13. Gambar grafik pie diatas menunjukan Perkerjaan dari responden, $22 \%$ menjawab bekerja sebagai TNI/Polri/PNS, 32\% responden berkerja sebagai Swasta, untuk Pelajar/Mahasiswa mencapai $41 \%$ dan Pekerjaan Lainnya 5\%.Dari hasil tersebut persentase terbanyak adalah Pelajar/Mahasiswa sebesar $41 \%$.

Gambar 14. diatas menunjukan respon responden mengenai kesan selama menggunakan jasa penyeberangan Ujung-kamal, 3\% responden sangat puas dengan jasa penyeberangan Ujung-Kamal, begitu juga dengan 37\% responden merasa cukup puas dengan jasa penyeberangan, lalu ada $45 \%$ responden puas dengan jasa penyeberangan dan $15 \%$ responden menjawab tidak puas lalu $0 \%$ responden yang menjawab sangat tidak puas. Dari hasil tersebut persentase terbanyak adalah puas dengan persentase $45 \%$.qq.

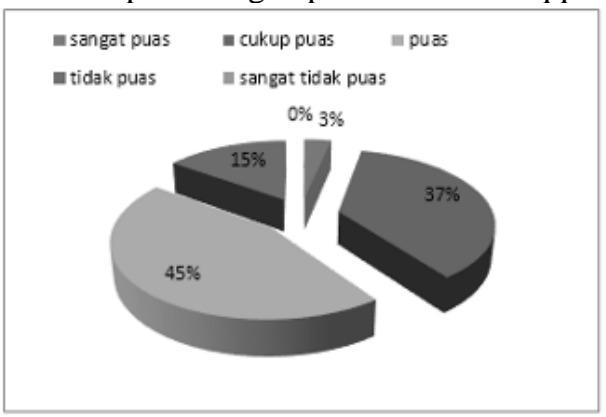

Gambar 14. Kesan Saat Menggunakan Penyeberangan Ujung-Kamal.

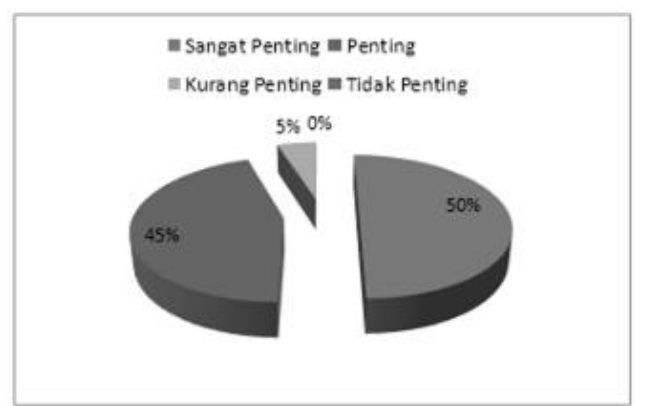

Gambar 15. Eksistensi Penyeberangan Ujung-Kamal mengingat Jembatan Suramadu telah beroperasi.

Gambar 15. diatas menunjukan respon responden mengenai seberapa penting penyeberangan Ujung-Kamal mengingat telah ada jembatan Suramadu, 50\% responden memilih sangat penting, $45 \%$ responden memilih penting adanya penyeberangan Ujung-kamal walaupun telah ada jembatan suramadu, lalu terdapat $5 \%$ responden memilih kurang penting dan $0 \%$ responden memilih tidak penting. Dari hasil tersebut persentase terbanyak adalah sangat penting dengan persentase $50 \%$.

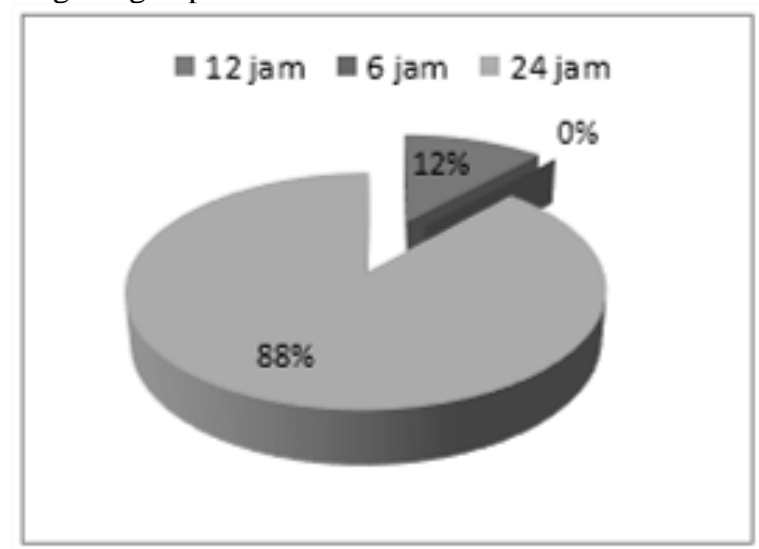

Gambar 16. Harapan Responden teradap Jadwal Operasi Kapal.

Gambar 16. diatas menunjukan respon responden mengenai harapan berapa lama waktu operasi penyeberangan Ujung-Kamal dalam sehari, dari $12 \%$ responden setuju jika operasi penyeberangan Ujung-kamal selama 12 jam dalam sehari, terdapat $0 \%$ responden memilih 6 jam dalam sehari dan $88 \%$ responden memilih waktu operasi penyeberangan Ujung-Kamal selama 24jam dalam sehari. Dari hasil tersebut persentase terbanyak adalah 24 jam sebanyak $88 \%$.

\section{B. Analisis Biaya Transportasi}

Biaya transportasi laut meliputi dari biaya tetap (fixed cost) dan biaya tidak tetap (variable cost). Untuk mendapatkan nilai dari fixed cost dan variable cost, maka beberapa asumsi seperti data jarak pelayaran, spesifikasi dan variasi armada, 
biaya pengadaan kapal, bahan bakar, hingga biaya pelabuhan digunakan sebagai dasar perhitungan pada model optimisasi.

\begin{tabular}{|c|c|c|c|c|c|c|c|}
\hline Rekapitulasi & \multicolumn{2}{|c|}{ KMP Tongksl } & \multicolumn{2}{|c|}{ RMP Ggighthada } & \multicolumn{3}{|c|}{ KMP Jokutole } \\
\hline \multirow{3}{*}{ Capital Cest } & Ap & 2581.514 & $b$ & $5 \mathrm{~m} * 3,50$ & if & $2, x 0 \mathrm{sA2}$ & Jaen \\
\hline & $A_{p}$ & 3515315 & b & $136,754,59$ & If & gakn: & fedin \\
\hline & $\mathrm{BP}$ & $542,310,54$ & 30 & $2,121,96,911$ & in & L.118,50 A50 & jahun \\
\hline \multirow{3}{*}{$\begin{array}{l}\text { Optrational } \\
\text { Cest }\end{array}$} & Fe & 322,006 & 32 & $10566,9 \pi$ & if & $9,284,595$ & Iman \\
\hline & Ap & $2 \mathrm{x} \times \mathrm{s}(0)$ & $b$ & 200,02250 & is & $226,15 \times 600$ & fadan \\
\hline & $a_{0}$ & 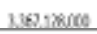 & b & Moshativice & $H_{p}$ & 1 morensm & Iatun \\
\hline \multirow{3}{*}{ Vtsage Cost } & is & $2,0,0)$ in & b & $22,4 \%, 552$ & $b$ & $2.1 .4 \mathrm{x}$ & ierri \\
\hline & is & 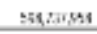 & b & 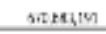 & to & $x: 31,54$ & isuizn \\
\hline & is & $7,184: 2 x, 201$ & b & LEt & 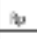 & $3 \leq 42,2025$ & istun \\
\hline \multirow{3}{*}{ TOTAL. } & 13 & 31, $24: 12$ & b & unge: & b & Аรभม⿱亠 & i-zri \\
\hline & is & 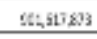 & b & $2,20, \operatorname{sic} 520$ & 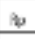 & 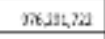 & isusn \\
\hline & $t_{1}$ & $21,84,3548$ & b & 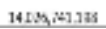 & 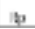 & $5,3: 1940$ s. & Gatum \\
\hline
\end{tabular}

Gambar 17. Total Cost.

Gambar 17. Total biaya merupakan komponen dari fixed cost (biaya tetap) dan variable cost (biaya variabel). Fixed cost merupakan penjumlahan dari harga kapal, biaya asuransi, biaya reparasi, biaya kru, sedangkan variable cost perjumlahan dari biaya bahan bakar dan biaya pelabuhan, dengan jumlah frekuensi kapal dalam 1 (satu) tahun. Berikut akan dijelaskan proporsi dari masing-masing komponen biayanya

\section{Hasil Optimasi}

Tabel 1.

Hasil Optimasi

\begin{tabular}{lcl}
\hline \hline & Trip & Total Cost \\
\hline Total KMP Gajahmada & 10 & Rp 14,887,966 \\
Total KMP Jokotole & 8 & Rp 11,230,715 \\
Total KMP Tongkol & 0 & - \\
\cline { 2 - 3 } & & Rp 26,118,681 \\
\hline \hline
\end{tabular}

Dari hasil optimasi didapatkan 2 kapal yang terpilih dari jumlah keseluruhan armada kapal yang berjumlah 3 kapal. Dari kapal terpilih tersebut di dapatkan biaya voyage cost sesusai dengan trip yang telah di optimasikan.

Tabel 1 dari hasil optimasi yang di dapat, hanya 2 kapal yang beroperasi dari jumllah keseluruhan kapal yang berjumlah 3 kapal, yaitu KMP Gajah Mada dan KMP Jokotole. Dimana KMP Gajah Mada melayani T. Dimana KMP Gajah Mada melayani Trip dalam seharinya sebanyak 10 Trip dalam seharinya sebanyak 10 Trip sedangkan untuk KMP Jokotole hanya melayani Trip dalam seharinya sebanyak 8 Trip. Untuk Total cost tersebut KMP Gajah Mada yang memiliki total Cost terbesar yaitu Rp.14.887.966 per hari

\section{Analisis Sensitivitas}

Analisis sensitivitas Jumlah penumpang terhadap jumlah armada kapal. Analisis sensitivitas dilakukan pada 3 kapal yaitu KMP Tongkol, KMP Gajah Mada dan KMP Jokotole.dimana jumlah dari setiap penumpang akan di tambah masing-masing sebanyak 20\%,40\% dan $70 \%$ dimana $70 \%$ adalah maksimum penjumlahan untuk sensitivitas tersebut di karenakan kapasitas kapal akan kelebihan muatan jika di tambah lebih dari $70 \%$.

Tabel 2 menjelaskan tentang kondisi saat telah dioptimasi kapal yang beroperasi hanya dua kapal yaitu KMP Gajah
Mada dan KMP Jokotole dengan trip sebanyak 10 dan 8 dalam sehari, saat jumlah penumpang ditambah $20 \%$, KMP Tongkol mulai beroperasi namun hanya 2 Trip saja dalam sehari untuk KMP Jokotole ada perubahan dengan tripnya yaitu menjadi 10 trip dalam sehari. Lalu saat jumlah penumpang di tambah $40 \%$ trip dari KMP Tongkol naik menjadi 6 trip dalam seharinya dan saat di tambah70\% trip dari KMP gajah mada naik menjadi 10 trip.

Tabel 2.

Hasil Sensitivitas

\begin{tabular}{|c|c|c|c|c|}
\hline $\mathrm{X}$ & & $\mathrm{Y}$ & & \multirow{4}{*}{ Trip } \\
\hline \multirow{3}{*}{$\begin{array}{l}\text { Prosentase } \\
\text { Jumlah } \\
\text { Penumpang }\end{array}$} & \multicolumn{3}{|c|}{ Unit Cost } & \\
\hline & KMP & KMP & KMP & \\
\hline & Tongkol & Jokotole & Gajahmada & \\
\hline $70 \%$ & Rp12,715,711 & Rp14,038,393 & Rp14,887,966 & $10 ; 10 ; 10$ \\
\hline $40 \%$ & Rp12,715,711 & Rp14,038,393 & Rp14,887,966 & $6 ; 10 ; 10$ \\
\hline $20 \%$ & $\mathrm{Rp} 2,543,142$ & Rp14,038,393 & Rp14,887,966 & $2 ; 10 ; 10$ \\
\hline $0 \%$ & & Rp11,230,715 & Rp14,887,966 & $8 ; 10$ \\
\hline
\end{tabular}

\section{KESIMPULAN DAN SARAN}

\section{A. Kesimpulan}

\section{1) Kondisi eksisting,}

Jumlah Kapal yang beroperasi tidak menentu, dalam sehari terkadang 3 hingga hanya 1 kapal yang beroperasi, di karenakan kapal sedang annual docking, disewa, ataupun rusak. Ketidak pastian jadwal penyeberangan mengakibatkan para penumpang tidak memiliki acuan keberangkatan dan kedatangan kapal.

2) Model operasi kapal yang optimal adalah sebagai berikut:

Armada kapal Penyeberangan Ujung-Kamal yang akan melayani penumpang berjumlah 2 kapal dari jumlah keseluruhan armada yaitu 3 kapal, dengan Jadwal yang telah di optimasi hanya melayani 10dan 8 trip dalam sehari

Dari hasil optimasi penjadwalan tersebut di dapatkan minimum unit cost yaitu sebesar Rp.Rp14.887.966 per hariuntuk KMP Gajah Mada dan Rp. Rp11.230.715 per hari untuk KMP Jokotole.

\section{B. Saran}

1. Perlu adanya membuka rute baru

2. Membuat Pelabuhan wisata di Pelabuhan Kamal, mengingat Pulau Madura kaya akan Tradisi dan Budaya.

\section{DAFTAR PUSTAKA}

[1] E. A., "Peramalan pengguna kapal ferry ujung-kamal dengan metode inverensi," 2016.

[2] PT.ASDP Indonesia, "Spesifikasi dan pola operasi kapal PT.ASDP indonesia ferry (persero) cabang surabaya."

[3] S. H., "Perkembangan industri dan pendapatan daerah bangkalan sebelum dan sesudah pembangunan jembatan suramadu," 2013.

[4] E. Akbarwati, "Revitalisasi kawasan pelabuhan kamal di madura," 2013.

[5] E. Khatherine, "Metafora transisi dalam redesain terminal pelabuhan kamal madura sebagai kawasan wisata," 2013.

[6] D. R., "Perbedaan antara jembatan suramadu dan pelabuhan kamal, pengaruh jarak terhadap perkembangan wilayah di kabupaten bangkalan," 2014. 